J. Perinat. Med. 1 (1973) 192

\section{Evaluation of the DHEA-S test at an index of fetoplacental insufficiency}

\author{
Z. K. Stembera, J. Herzmann
}

Intitute for the Care of Mother and Child, Prague-Podoli Czechoslovakia Research Institute of Endrocrinology, Prague, Czechoslovakia

Received December 13, 1972. Accepted January 10, 1973.
In countries where prenatal care as well as care of the parturient is well organized, placental dysfunction is nowadays one of the most frequent causes of the perinatal mortality in the last trimester of pregnancy. Timely (i. e. antenatal) diagnosis of this condition is thus one of the basic requirements for the prevention not only of perinatal mortality but also of morbidity. The diagnositc importance of estriol in the urine of pregnant women in cases of fetal danger has been confirmed in the literature of the last decade. Numerous authors confirm however, that the daily variance of estriol clearance - $20-50 \%$ - is a drawback which, in part, lessens the reliability of this method in cases of low or gradually decreasing values. A new functional element, rendering the diagnostic importance of estriol level more precise, is achieved through the administration to the mother of dehydroepiandrosterone-sulphate (DHEA-S) which is metabolized by the placenta and the fetus to estriol. The functional activity of the whole fetoplacental unit is judged either from the increased amount of excreted estriol in 24 hours as suggested by LAURITZEN [2], or from the degradation rate of the administered DHEA-S which v. D. CRABbEN [1] determines by measuring the estriol excretion peak in urine samples withdrawn every two hours.

\section{Methods}

The above mentioned DHEA-S test was modified so as to a) maintain the diagnostic significance of the values of estriol excreted (in $\mathrm{mg} / 24$ hours), uninfluenced by the administration of DHEA-S,

\section{Curriculum vitae}

Doc. Dr. ZDENeK K. ȘTEMBERA, Dr. Sc., is a leading scientific worker in the Research Institute for the Care of Mother and Child in Prague: He has been bead of the perinatology research group of this Institute for 15 years. He bas published some 150 papers mostly concerning perinatal topics and also two monographs: „Hypoxia of the Foetus" (1967) and „High Risk Pregnancy and the Child“ (1973). In addition, be edited the book "Intrauterine Dangers to the Foetus" (1967). He bas read papers at many congresses in Europe and in the USA. He is president of the Crech Perinatal Society; be has been elected president of the Preparatory Committee of the Fourth European Congress of Perinatal Medicine to be beld in Prague in 1974.

b) demonstrate the diagnostic significance of the two new elements, i. e. the rate and the intensity of the degradation of the administered DHEA-S to estriol,

c) eliminate the unfavorable effect of day-variation of estriol clearance (in $\mathrm{mg} / 24 \mathrm{hrs}$.) on the reliability of the method.

The test is performed and evaluated in the following way (Fig. 1). From the first two two-hourly urine samples withdrawn before DHEA-S administration (i. e. 6-8 a.m. and 8-10 a. m.), the initial estriol value is calculated as the first parameter (a). In the following four two-hourly samples (10 a. m.-6 a.m.), after $30 \mathrm{mg}$ DHEA-S I. V. administration (at $10 \mathrm{a} . \mathrm{m}$.), a further 3 parameters are evaluated: The time taken to reach the excretion peak (b), the height of the peak (c) and the total amount of excreted estriol in the four samples after. DHEA-S administration (d). In order to eliminate the effect of diurnal variation of estriol urine clearance, the initial value is 


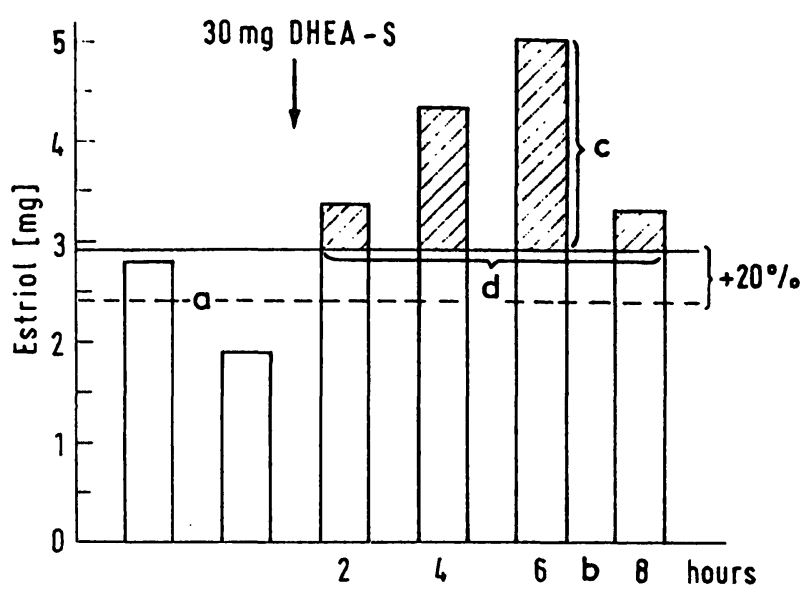

Fig. 1. Evaluation of the 4 parameters of the DHEA-S test: a) initial value (arithmetical means of two 2 hours urine samples before DHEA-S administration) in $\mathrm{mg}$, b) time of attaining the excretion peak after DHEA-S administration (in hours), c) magnitude of excretion peak in $\mathrm{mg}$ (calculated from the initial value increased by $20 \%$ ), d) total amount of excreted estriol within an 8 hour period in $\mathrm{mg}$ (calculated from the initial value increased by $20 \%$ ).

calculated as the arithmetic mean from the first two samples; the further 3 parameters are checked against this initial value to which $20 \%$ has been added. The $20 \%$ is added since Śtembera and HerzmanN [3] found that the 95\% confidence limit for two-hourly day-variation corresponded to the increase of the initial value by $20 \%$; this was noted from the study of 20 pregnant women in whom estriol clearance was followed in two-hourly urine samples without DHEA-S administration.

The clinical condition of the newborn immediately after delivery was employed as the objective criterion for the evaluation of the results of the DHEA-S test. All of the following cases could be divided into 4 groups accordingly: 1. Completely healthy newborns 2 . Newborns with postnatal depression (APGAR score 7 and less points 1 minute after delivery) 3 . Small-fordate newborns (according to Lubchenko) 4. Stillbirths.

If the test had been repeated several times on the same woman the one which was last performed within $1-5$ days prior to delivery was used for the comparison with the clinical state of the newborn. The estimation of estriol was performed according to ITTRICH. The recovery-rate in our laboratory is $97,45 \% \pm 1.75 \%$.

\section{Results}

In the preceding phase of this study ŠTEMBERA and Herzmann [3] found in 48 pregnant women that the value of the DHEA-S test could be

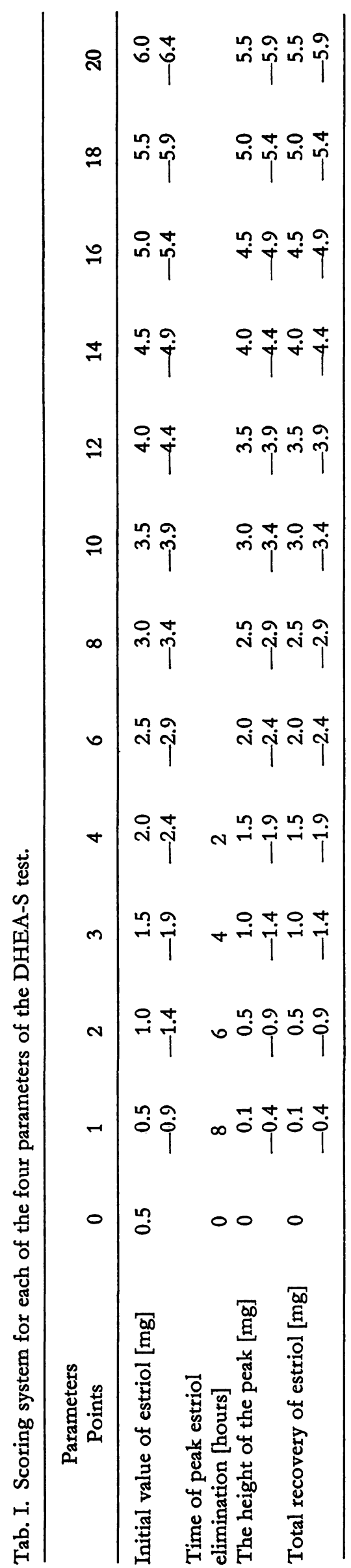


quantificated according to placental function. Each of the 4 above-mentioned parameters of the DHEA-S test $(a-d)$ was subdivided into several groups according to significance and for each of these subdivisions the respective number of points was stated (Tab. I). Their sum indicates the functional activity of the fetoplacental unit; the value of the index did indeed correlate well with the clinical condition of the newborn. In 16 out of 18 mothers whose newborns showed some deviation from the norm a low value of the test was found.

This was why, in the next phase of the study, the authors attempted to determine, by means of the DHEA-S test, a more detailed prediction of fetal state using a small computer. Each of the four parameters found $(a-d)$ was classified into 6 groups and, from the values obtained, a parameter diagnosis matrix was set up in 80 cases in which 100 examinations were performed. From the set up matrix, the probability of the individual diagnosis for each case was calculated. The calculations were performed using a small CLARY DE-600 computer.

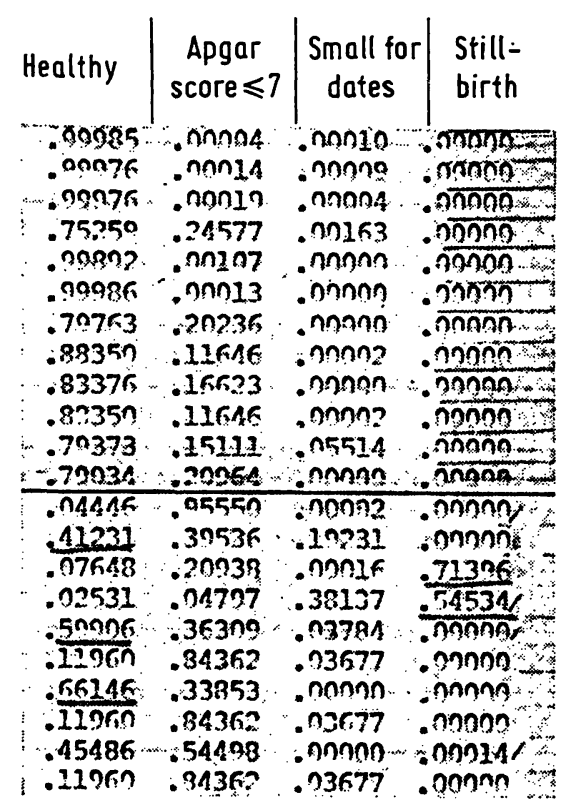

Fig. 2. Original computer output determining one of the four possibilities of fetal development for each case; for classifying into one of the four groups, the highest of the 4 digits in each case is decisive (e. g. in the first 12 cases the diagnosis "healthy newborn" was stated, whereas the 13th case was diagnosed as a "newborn with a decreased APGar score").
The output of the computer (Fig.2) consists of 4 sets of figures for each case, characterizing 4 possible clinical predictions. The value of the figure in a group determines the probability that the given case falls within that group; e. g., the higher the digit in the first column, the higher the probability of a healthy newborn; on the other hand, the higher the digit in the last column, the higher the possibility of a stillbirth.

The comparison of the prognoses, thus found, with the actual clinical state of the newborn revealed, in each individual case (Fig. 3A), that in two thirds of all healthy newborns the prodiction was correct with a probability higher than $70 \%$. Such a high probability of a healthy newborn was not found in a single case in the other 3 groups of newborns; all cases in the last two groups (small-for-dates and stillbirths) showed only a very low probability (i. e. $20 \%$ or less) of becoming healthy newborns. Such a low probability was also found in two thirds of the cases with postnatal depression, yet only in 3 out of 46 healthy newborns.

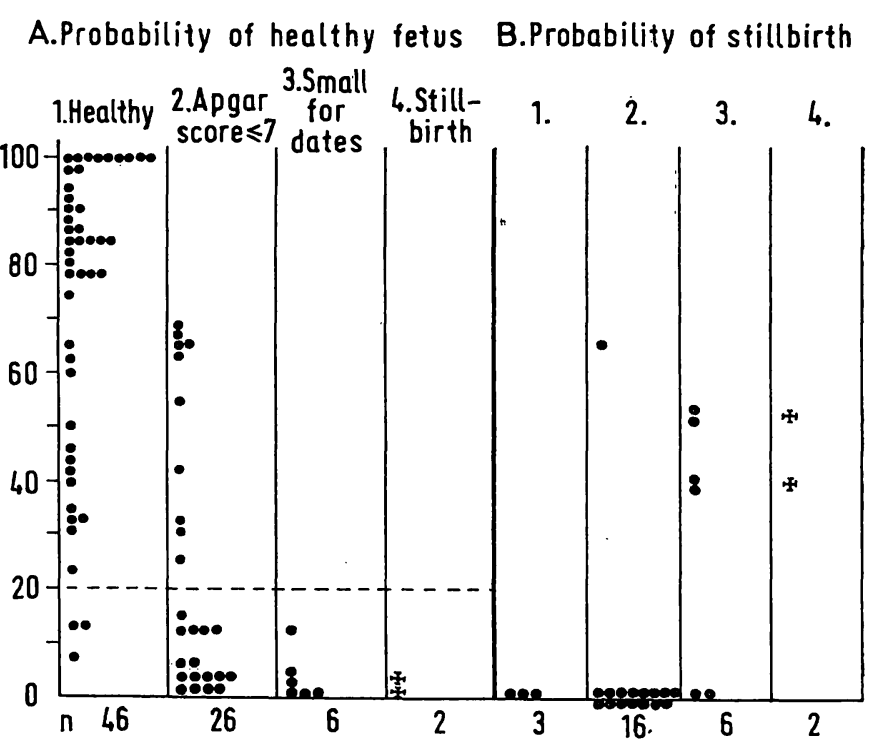

Fig. 3. Comparison of the computed prognoses of fetal development with the actual clinical state of the newborn: A) Percentage probability of a healthy newborn in all 80 cases, divided into four groups according to the acutal clinical state after delivery, B) Percentage probability of a stillbirth in 27 cases in whom the expectation of there being a healthy fetus was very low (see Fig. 3A - cases below the dashed line under $20 \%$ ): 
A further differentiation of the cases with a very low probability of healthy development can be performed by determining the prediction of stillbirths (Fig. 3B). In this differentiation both cases in the stillbirth group show a high probability of stillbirth, whereas all 3 cases of healthy newborns (first group) show zero probability of stillbirth. When in 5 cases of the remaining two groups a high probability of stillbirth was apparent, pregnancy, in 4 out of these five cases, was terminated by elective Caesarean section, as a preventive measure, because of the indication of danger to the fetus. In the same way we can perform further differentiation of each of the remaining less serious cases (in which our prediction of the birth of a healthy newborn was only between $20-70 \%$ ), for example by determining the probability of neonatal depression.

The prediction of fetal development, according to the principle of conditioned probability, was used in a further 33 cases of high risk pregnancy in the following phase of the study. In $84 \%$ of these cases, the prediction of fetal development correlated with the actual clinical condition of the newborn. The calculation was carried out on the basis of the above matrix set up from the examination of 80 cases. The possible combinations offered by the 4 parameters divided into 6 groups are nevertheless many times greater; this is why the greater the number of cases in the matrix the greater the reliability of predicting fetal development in high risk pregnancies.

\section{Discussion}

The setting up of a parameter-diagnosis matrix and the comparison of the prediction with the actual state of the fetus is based on the presumption of a "fix" clinical diagnosis, i. e. the neonatal state, resulting from a good fetoplacental function or dysfunction. However, with this "fix" diagnosis further factors are involved; these are capable of influencing the prediction of fetal state both favorably or unfavorably:

a) temporary neonatal depression of the newborn originating in the last phase of delivery due to the umbilical cord being tightly wound around the fetal neck;

b) temporary neonatal depression caused by narcotics used in the surgical termination of labor;

c) in severe placental insufficiency it is possible, by premature termination of pregnancy (i. e. by induction of labor or by elective Caesarean section), to avoid severe progressive fetal dystrophia or stillbirth. However, waiting for several days or weeks for spontaneous beginning of labor would probably be even more deleterious for the fetus than suggested by the calculation.

For the evalutation of the DHEA-S test the last test was always carried out within $1-5$ days before delivery, but, owing to variation in the gestational period, this was anywhere between the 36th-43rd week of pregnancy. The time factor, therefore, undoubtedly also very important in placental physiology, has not so far been considered in the evaluation of the DHEA-S test.

Although the DHEA-S test was used in all high risk pregnancies, it nevertheless seems very probable that placental dysfunction (cf. diabetes, toxemia, $\mathrm{Rh}$-isoimmunisation, overdue birth) was not the main cause of danger in all of them.

The two methods of evaluating the DHEA-S test, i. e. the scoring system expressing the degree of placental dysfunction (Tab. I) and the prediction of the fetal state using conditioned probability, represent two different approaches for the assessment of danger to the fetus. In the scoring system we merely try to quantify the degree of placental dysfunction. In predicting the fetal state we nevertheless try, besides determining the limit between the physiological and pathological state, to differentiate the consequence of placental dysfunction at the same time. Although the results of this study seem to indicate that the prediction of intrauterine fetal development using a small-size computer could render effective help for obstetrical practice, two basic facts should always be kept in mind, viz:

1. The DHEA-S test is only one of the many methods of determining fetal danger due to 
placental dysfunction. However, as the fetus is threatened in many different ways, we cannot expect one single method to diagnose reliably every intrauterine fetal danger.

\section{Summary}

Four parameters of DHEA-S were evaluated: a) initial value, b) time of peak excretion, c) height of the peak, d) total amount of excreted estriol after DHEA-S administration (Fig. 1). The last three data were evaluated by checking them against the initial value increased by $20 \%$. In this way the diagnostic significance of the excreted estriol, uninfluenced by DHEA-S is maintained utilizing at the same time both functional elements, i. e. the rate as well as the intensity of DHEA-S degradation to estriol, in which the metabolism of both the placenta and the fetus participates. In this way we simultaneously exclude the unfavorable effect of day variance of estriol excretion. The clinical condition of the newborn is classified into 4 groups according to degree of severity, viz.: healthy newborns, newborns with postnatal depression (decreased APGAR score), small-for-dates and stillbirths.

Quantification of the DHEA-S test was performed using 48 women, comparing the clinical state of the newborn
2. A computer can nevẹ r replace a physician but can help him effectively. In the final analysis it is the physician who must take the overall responsibility and make the diagnosis.

with the above-mentioned four test parameters. For each of the parameters the respective number of points was calculated (Fig. 3). Their sum expressed the functional activity of the fetoplacental unit, which correlated well with the clinical state of the newborn. For determining a more detailed prediction of the fetal state the above four parameters were subdivided into six classes according to degree of severity; thus from 100 examinations a parameterdiagnosis matrix was set up. From the set up matrix, the conditioned probability of the individual prediction in each case was calculated using a small computer (Fig. 2). In a further 33 cases of high risk pregnancy the prediction thus determined, correlated in 84 percent with the actual clinical state of the newborn. It will be possible to increase the reliability percentage of the DHEA-S test by supplementing the matrix with further cases. The prediction is, however, distorted by various factors affecting the clinical condition of the newborn.

Keywords: Computers, diagnosis diferential, estriol, fetus, placental hormones, pregnancy complications, prenatale care.

\section{Zusammenfassung}

Modifizierter DHEA-S-Test als Index für die fetoplazentare Insuffizienz

Vier Parameter unter DHEA-S wurden ausgewertet: a) der Initialwert, b) die Zeit der maximalen Ausscheidung, c) die Höhe der maximalen Ausscheidung und d) die Gesamtmenge des ausgeschiedenen Östriols nach Gaben von DHEA-S. Die letzten drei "Kriterien wurden ausgewertet durch die Gegenüberstellung mit dem um 20\% erhöhten Initialwert (Fig. 1). Auf diese Weise bleibt die diagnostische Signifikanz des ausgeschiedenen Östriols aufrechterhalten ohne störenden Einfluß von DHEA-S unter gleichzeitiger Berücksichtigung funktioneller Gesichtspunkte, nämlich der Rate und Intensität des Abbaus von DHEA-S zu Östriol, woran der Stoffwechsel der Plazenta und des Feten in gleicher Weise beteiligt ist. So schlossen wir gleichzeitig auch den ungünstigen Effekt der Tagungsschwankungen in der Östriolausscheidung aus. Der klinische Zustand der Neugeborenen wird in 4 Gruppen eingeteilt entsprechend dem Schweregrad, nämlich: Gesundes Neugeborenes, postnataler Depressionszustand (herabgesetzter ApGaRScore), Dysmaturität und Totgeburt.

Eine quantitative Auswertung des DHEA-S Testes wurde bei 48 Frauen durchgeführt, indem der klinische $\mathrm{Zu}$ - stand des Neugeborenen mit den oben angegebenen 4 Parametern verglichen wurde (Fig. 3). Für jeden der Parameter wurde eine entsprechende Punktzahl ermittelt. Die Gesamtzahl der Punkte war Ausdruck für die funktionelle Aktivität der feto-plazentaren Einheit, was gut mit dem klinischen Zustand des Neugeborenen korrelierte. Um eine mehr detaillierte Prognose der fetalen Entwicklung zu ermitteln, wurden die oben genannten 4 Parameter in 6 Stufen aufgeteilt, entsprechend dem Schweregrad, und aus 100 Untersuchungen eine Matrix mit den diagnostischen Parametern aufgestellt. Mit Hilfe dieser Matrix wurde unter Verwendung eines Kleincomputers die Wahrscheinlichkeit der individuellen Prognose eines jeden Falles ermittelt (Fig. 2). In weiteren 33 Fällen von Risikoschwangerschaften entsprach die so ermittelte Prognose in $84 \%$ dem echten klinischen Zustand des Neugeborenen. Es wird möglich sein, die prozentuale Zuverlässigkeit des DHEA-S Testes weiter zu verbessern, indem man die Matrix durch weitere Fälle ergänzt. Daneben wird aber die ermittelte Prognose in ungünstiger Weise durch verschiedene Faktoren beeinflußt, die den klinischen Zustand des Neugeborenen betreffen.

Schlüsselwörter: Computer, Differentialdiagnose, Östriol, Fetus, Plazentarhormone, Schwangerschaftskomplikationen, pränatale Betreuung. 


\section{Résumé}

Index d'insuffisance foeto-placentaire

Quatre mesures ont été faites pour la DHEA-S: a) Ia valeur initiale, b) le moment du pic d'excrétion, c) la hauteur du pic, d) la quantité totale d'oestriols excrétés après administration de DHEA-S. On a évalué les trois dernières données en les contrôlant par rapport à la valeur initiale augmentée de $20 \%$. De cette façon on conserve sa valeur diagnostique à l'excrétion d'oestriols non modifiée par la DHEA-S, en utilisant en même temps les deux élèments fonctionnels, c'est-à-dire la vitesse ainsi que l'intensité de la dégradation de la DHEA-S en oestriol, dans lequel entrent en jeu la placenta et le foetus. De cette façon, nous avons exclu en même temps l'effet défavorable des variations d'excrétion de l'oestriol au cours du nyctémère. L'état clinique du nouveau-né a été classé en 4 groupes, c'est-à-dire: nouveau-né vigoureux, avec dépression post-natale (score d'APGAR bas), hypotrophique et prématuré.

On a pratiqué la mesure quantitative de la DHEA-S chez 48 femmes en comparant l'état clinique du nouveau-né avec les quatre paramètres sus-décrits. $\mathrm{A}$ chaque paramètre on a attribué un nombre correspondant de points. Leur somme exprimant l'activité fonctionelle de l'unité foeto-placentaire, et elle présentait une bonne corrélation avec l'état clinique du nouveau-né.

Pour établir un pronostic plus précis du développement foetal les quatre paramètres ont été répartis en six classes selon la gravité de l'état foetal, et pour 100 examens une étude de corrélation paramètre-diagnostic a été réalisée. $\mathrm{A}$ partir de cette matrice, la probabilité de chaque pronostic particulier était calculée à l'aide d'un petit calculateur. Pour les 33 cas suivants de grossesse à haut risque le pronostic déterminé de cette façon donnait une bonne corrélation avec l'état réel du nouveau-né dans $84 \%$ des cas. Il sera possible d'améliorer le pourcentage de fiabilité du test à la DHEA-S en complétant la matrice avec d'autres cas. Par ailleurs, le pronostic ainsi déterminé est faussé par différents facteurs affectant l'état clinique du nouveau-né.

Mots-clés: Ordinateurs, diagnostic différentiel, oestriol, foetus, hormones placentaires, complications de la grossesse, soins prénatals.

\section{Acknowledgements}

The authors are indebted to Messrs. Hoffmann-La Roche \& Co., Basle for their kindly supplying the authors with DHEA-S injections in this study.

The article was delivered in an abbrevitad form at the 3rd European Congress of Perinatal Medicine in Lausanne, April 1972.

\section{Bibliography}

[1] v. D. Crabeen, H., K. Hammacher, Ch. Werner, H. Schmidt-Elmendorf, A. Kunkel, E. Kaiser: The early diagnosis of the placental insufficiency by the new dehydroepiandrosteron-sulfate load test to the cardiotocography, placental histology and other methods relating thereto. Acta endocr. (Kbh.) 138 (1969) 244 (Suppl.)
[2] Lauritzen, C.: Ausscheidung und Stoffwechsel von DHEA in der normalen und pathologischen Schwangerschaft. In: Das Testosteron - Die Struma, Springer, Berlin 1968

[3] Štembera, Z. K., J. HerzmanN: Vyšetřování estriolu po DHEA-S jako test placentární insuficience. Čs. Gynek. 36 (1971) 597

Doc. Dr. Z. K. Stembera, Dr. Sc. Institute for the Care of Mother and Child Prague-Podolí

Czechoslovakia 